Migration and Identity Processes among First-Generation British South Asians

\author{
Rusi Jaspal \\ De Montfort University, Leicester, UK
}

\begin{abstract}
There has been little scholarly attention to the identities and migratory experiences of first-generation British South Asians, especially from social psychologists. Drawing upon Identity Process Theory, this article examines the inter-relations between migration and identity processes among twenty first-generation British South Asians. The interview data were analysed using qualitative thematic analysis. Results suggested that migration was perceived as a means of enhancing identity and that following migration individuals acquired a "higher" social status in the homeland. Moreover, the psychologically traumatic aspects of migration, such as the loss of community and "otherisation" from one's ethnic ingroup, were outlined. It is argued that migration can have profound socio-psychological implications and that decades later it can continue to shape individuals' sense of self and their attachment to relevant social categories. Furthermore, migration has important outcomes for the extent and nature of British national identification as well one's relationship with the ethnic "homeland."
\end{abstract}

Keywords: identity, migration, ethnic identity, national identity, homeland

Acknowledgements: The author would like to thank members of the Self and Identity Research Group, as well as the anonymous reviewers, for providing constructive comments on previous versions of this manuscript.

Citing this article: Jaspal, R. (2015). Migration and identity processes among first generation British South Asians. South Asian Diaspora, 7(2), 79-96

Correspondence: Dr Rusi Jaspal, Self and Identity Research Group, Faculty of Health and Life Sciences, De Montfort University, Leicester LE1-9BH, UK. E-mail: rusi.jaspal@cantab.net 


\section{Migration and Identity Processes among First-Generation British South Asians}

The inter-relations between migration, community and identity have long been the focus of academic debate. Questions have been raised about the extent to which migrants identify with their "homeland" and host society respectively, the qualitative nature of their relationship with both contexts, and the construction of "communities" within the host society (Ballard, 1994; Sam and Berry, 2006). These issues have been examined principally through the lenses of diaspora, transnationalism and biculturalism (Ballard, 1994; Vertovec, 2009). More recently, social psychologists have focused upon developing theories of immigrants' identities, wellbeing and acculturation strategies (e.g. Sam and Berry, 2006).

Social scientists have begun to study the identities and migratory experiences of the South Asian minority community in Britain, following media observations that secondgeneration British South Asians (BSA) are inter alia "suspended between cultures", susceptible to radicalisation, and unable to "integrate" within dominant British society (Ghuman, 2003; Saeed, 2007). However, there has been less attention to first-generation BSA, especially from social psychologists. This is important because this group has faced migration, and migration can radically shape how people view themselves, how they position themselves in relation to social categories (e.g. "British", "Indian", "Asian") and how they, accordingly, relate to others. Drawing upon Identity Process Theory, this article examines the inter-relations between migration and identity processes among first-generation BSA.

\section{The South Asian presence in Britain}

The term "British South Asian" constitutes a superordinate ethno-cultural category, used typically to refer to individuals of Indian, Pakistani, Bangladeshi or Sri Lankan descent. National identification among BSA is a complex issue - many feel that they are not accepted by their White British co-nationals and, therefore, cannot be British; some view themselves as British citizens but do not have a British national identity; and many people have a fluid sense of national identity and fluctuate in their levels of national attachment (Jaspal, 2011). To better understand national identification, it is necessary to examine briefly the sociology of BSA. The socialisation of first-generation BSA in largely collectivist societies in India and Pakistan, which prioritise the notion of kinship ("biraderi" and "izzat"), coupled with their commitment to the "myth of return" (to the Subcontinent), rendered their sense of national identity largely unproblematic in the early phase of settlement in Britain. They simply did not lay claim to a British national identity and saw themselves first and foremost as Indians or Pakistanis (Ballard, 1994). Intergroup relations with the White British majority were not positive - South Asian migrant were acutely aware of the widespread social representation among the White British majority that "colored immigrants" posed a threat to British society, in both social and economic terms (Brah, 1996).

Today, individuals of South Asian descent make up 7.5 per cent of the population in England and Wales, making them the largest ethnic minority category in Britain. ${ }^{1}$ Furthermore, many first-generation BSA who arrived in the 1960s and 1970s in order to fill a labour shortage in the largely industrial towns and cities of Northern England and the Midlands have now spent most of their lives in the UK. The vicissitudes of first-hand experience of living in Britain (e.g. experiences of racism; upward social mobility) have certainly shaped the way that immigrants to Britain view and relate psychologically to Britishness. Britain is no longer viewed solely as the economic haven it represented during

\footnotetext{
${ }^{1}$ Office for National Statistics 2011 http://www.ons.gov.uk/ons/rel/census/2011-census/key-statistics-for-localauthorities-in-england-and-wales/rpt-ethnicity.html\#tab-Ethnicity-in-England-and-Wales
} 
the early phases of settlement (Hiro, 1973), but rather as "home" to most BSA. Moreover, it is plausible that settlement in Britain (and hence reduced contact with their countries of origin) has shaped the ways in which migrants, conversely, perceive and relate psychologically to the ethnic homeland. In order to examine the impact of these factors for identity, this study focuses upon the cohort of first-generation BSA that migrated to Britain between the 1960s and 1980s. Their accounts are examined through the lens of Identity Process Theory.

\section{Identity Process Theory}

Identity Process Theory (IPT) (Breakwell, 1986; Jaspal and Breakwell, 2014) is offered as a framework for understanding the inter-relations between migration and identity. IPT proposes that identity construction is guided by various identity principles, which specify the optimal end-states for identity. These include:

- continuity across time (continuity);

- uniqueness or distinctiveness from others (distinctiveness);

- feeling confident and in control of one's life (self-efficacy);

- feelings of personal worth (self-esteem);

- the need to maintain feelings of closeness to and acceptance by others (belonging);

- the motivation to establish feelings of compatibility between identity elements (psychological coherence).

Individuals assimilate and accommodate those identity elements (e.g. being British, being a migrant) which provide optimal levels of the identity principles, and they avoid those elements which jeopardise these principles. IPT suggests that when these principles are impeded, for instance by changes in one's social context, identity is threatened and the individual will engage in strategies for coping with the threat. A coping strategy is defined as "any activity, in thought or deed, which has as its goal the removal or modification of a threat to identity" (Breakwell, 1986, 78).

In the only study to have examined migration from the perspective of IPT, Timotijevic and Breakwell (2000) focused upon immigrants to Britain from the former Yugoslavia following the outbreak of civil war. The authors found that the continuity and self-efficacy principles of identity were most susceptible to threat as a result of migration, although it must be noted that their participants had encountered "radical socio-political upheaval" (355), which is markedly distinct from the experience of most South Asian economic migrants to Britain during the 1960s and 1970s. For many participants, identity was chronically threatened because the sources of threat had not necessarily disappeared individuals had resiliently deployed strategies for coping with the threat but the threats themselves remained. The study showed identity's susceptibility to threat and the resilient human drive to fight threat.

\section{Identity and migration among British South Asians}

Most studies of BSA have focused upon the second-generation. Ghuman's (2003) research suggests that, due to experiences of racism both in and outside of school, BSA may question their sense of belonging to Britain (see also Hussain and Bagguley, 2005). Perceived belongingness in Britain can be further understood in the context of research into the "boundaries" of Britishness, which govern how individuals perceive the membership criteria for British national identity. Similarly, Vadher and Barrett $(2009,454)$ noted that BSA "employ a multiplicity of different ways of thinking about and relating to the "national' culture and the 'national' community which are fluid and context-dependent and much more complex than a unidimensional conceptualization implies." These studies demonstrate that social, cultural, temporal and, of course, psychological factors interact in determining how 
accessible (or not) British national identity is to ethnic minority groups. Indeed, in secondgeneration BSAs' accounts of their national identity, many invoke narratives of suffering and achievement, the ups and the downs of their parents, the first-generation, which clearly influences how they feel about Britishness (Jaspal, 2011). Hence, it is important to examine the psychological backdrop of migration, against which individuals may be constructing "boundaries" of Britishness.

Acculturation has been the dominant paradigm in socio-psychological accounts of migrants' adjustment to their host society. In a survey study of acculturation among young South Asians in Australia, Ghuman (2000) found that his respondents were generally less integrated than both Canadian and BSA, which he attributed to the "anti-Asian" feeling that was prevalent at the time of data collection. More recently, Robinson (2009) examined acculturation among second-generation BSA and found that, while British Indians generally favoured the integration strategy, British Pakistanis opted for the separation strategy. Indeed, BSA may, as a result of perceived discrimination, turn to their ethnic and religious groups for a sense of belonging (Jacobson, 1997). While it is true that there appear to be differences in acculturation orientations and national identification among British Indians and British Pakistanis, respectively, this study examines the commonalities in experiences of migration among first-generation members of both groups and the common impacts for their identities.

Perceived discrimination is an important determinant of one's level of attachment to Britishness and one's ethnic heritage. In their study, Hussain and Bagguley (2005) observed a difference in the ways in which first- and second-generation British Pakistanis laid claim to Britain and, thus, understood their national attachment. More specifically, "[t]he first generation still speak as if they are visitors, as temporary economic migrants. The second generation 'belong' through their place of birth" (420). Crucially, Hussain and Bagguley noted that the "citizenship identities" manifested by the first-generation were firmly rooted within their experiences and perceptions of migration to the Britain, while those of the second-generation developed on the basis of their socialisation in Britain. This too clearly illustrates the need to understand how first-generation BSA perceive and reflect upon their migratory experiences. This could contribute to an understanding of how they position themselves in relation to Britishness.

Hussain and Bagguley's (2005) emphatic distinction between national identity and "citizenship identity" overlaps somewhat with Kelman's (1997) typology of national attachment. For Kelman, sentimental attachment is emotional and entails a commitment to the national group's traditions and values, while instrumental attachment reflects a perception that the nation satisfies the practical, economic and educational interests of the individual and is devoid of an emotional attachment. Yet, it is unclear how delineable the two forms of attachment are among first-generation BSA.

In her research into US Indians, Hegde (1998) demonstrates that migrant identity entails the need to locate oneself in relation to old and new environments and to negotiate one's relationship with them. She argues that Otherness in the host context "continually echoes in the lives of immigrants, displacing and deferring their sense of coherence about self" (51). Thus, there is a need to examine migrants' continued relationship with their ethnic homeland. As Safran $(1991,84)$ observes, even within their host countries diasporas "continue to relate, personally or vicariously, to the homeland in one way or another, and their ethnocommunal consciousness and solidarity are importantly defined by the existence of such a relationship." Thus, an important psychological aspect of migration includes, on the one hand, how individuals relate and adjust to their host countries (which is frequently referred to as acculturation) and to their homeland.

The identities and experiences of second-generation BSA cannot be generalised to the first-generation for a number of compelling reasons. First, first-generation BSA have first- 
hand experience of living in both the Subcontinent and in Britain, while the secondgeneration tend to regard the Subcontinent as a holiday destination (Harris, 2006). Second, it appears that second-generation BSA may have access to several forms of social identification, while first-generation BSA often feel primarily connected to specific kin groups (Vadher and Barrett, 2009). Third, the first-generation may continue to view themselves as "visitors" and uncritically accept their outsider status, while the secondgeneration appears to be more vocal in affirming their rights as British citizens. Perceptions of migration may play an important role in shaping individuals' relationships with the homeland and Britain. Consequently, this study addresses the following research questions:

- How have migratory experiences impacted individuals' sense of self?

- How have these experiences shaped their relationships with relevant social categories?

\section{METHOD}

A sample of 20 participants was recruited from South Asian communities in the English East Midlands and West London. A snowball sampling strategy was employed, with the initial participants recruited from within the researcher's social networks. Small-scale qualitative interview studies tend to consist of a largely homogeneous sample (on factors relevant to the research questions) (Smith and Osborn, 2007). Accordingly, it was deemed advantageous to focus on the identities and experiences of just two of the ethnic groups under the category "British South Asian", namely British Indians and Pakistanis, due to their shared histories, experiences and identities (Ballard, 1994). There was no attempt to compare these groups. Furthermore, although there have been several waves of South Asian migration to Britain, the focus of this study was on the South Asians who arrived in Britain between 1960s and 1980s as unskilled or low-skilled manual labourers and their spouses. It is acknowledged that subsequent waves of migration may well exhibit distinct perspectives (Chatterji and Washbrook, 2013). Other participants were recruited at Indian and Pakistani community centres. Participants were first-generation BSA, all of whom had migrated to Britain between 1960 and 1985. 10 individuals were of Indian background (predominantly from the Punjab region of India) and the remaining 10 were of Pakistani descent (mainly from the Mirpur district of Pakistan). There were 10 males and 10 females, with a mean age of 54.6 years (SD: 4.9). Two participants had obtained undergraduate university degrees in the Subcontinent, fourteen participants were educated to GCSE-level, and the remaining four had no formal qualifications.

The interviews were guided by a semi-structured interview schedule consisting of ten exploratory, open-ended questions regarding self and identity; national and ethnic identities; reflections upon the reasons for migration; the early stages of settlement in Britain; relations with relevant outgroups; and attitudes towards Britain and the homeland. Interviews lasted between 60 to 90 minutes. They were digitally recorded and transcribed verbatim by the researcher.

The interviews were analysed using qualitative thematic analysis as described by Braun and Clarke (2006). This is considered useful since it allows the researcher to draw upon relevant theoretical concepts in order to add theoretical depth to the analysis. The analyst read the transcripts repeatedly in order to become as intimate as possible with the accounts. The right margin was used to note emerging theme titles which captured the essential qualities of the accounts. This procedure was repeated with every interview transcript. Two superordinate themes and the corresponding subthemes representing the 20 accounts were then ordered into a logical and coherent narrative structure. This study was not intended to be empirically generalizable but, given that the findings are related to emerging results from other studies, there may be a degree of transferability between similar research 
contexts. In the quotations presented below, three dots indicate where material has been excised; and other material within square brackets is clarificatory.

\section{ANALYSIS}

This section outlines the following two superordinate themes: (i) Migration to Britain as Identity Enhancement, and (ii) The Psychological Trauma of Migration.

\section{Migration to Britain as Identity Enhancement}

There was consensus that, prior to migration, dominant social representations ${ }^{2}$ of Britain within the Indian village context rendered migration a psychologically attractive prospect.

\section{Imagining the "Promised Land": Social Representations and Decision-Making}

Several participants highlighted the importance of others' first-hand accounts of life in Britain in their decision-making vis-à-vis migration. These first-hand accounts were reported to play an influential role in their decision-making because they were delivered by South Asians who had already settled in Britain. Respondents reported that migrants to Britain were held in great esteem and were, thus, able to create, encourage and disseminate social representations among South Asians in the Subcontinent (SAS) ${ }^{3}$ :

The stories she [his expatriate aunt] used to tell [..] that woman made this country seem like heaven or something. It was like the promised land for us (Ram,Indian)

It [Pakistan] was our home but it was a shit-hole [..] When they came back to Pakistan, the stories were just about a heaven on earth (Jamal,Pakistani)

Going to England, for us, was like a gift from God. Compared to what we had then, it was like a heaven or something like that (Karan,Indian)

As these accounts indicate, Britain was discursively "sanctified." Pargament and Mahoney (2005) define sanctification as the process whereby individuals can come to perceive virtually any aspect of their lives as having spiritual character and significance. More specifically, it is a process whereby "the ordinary becomes extraordinary" (180). Sanctification was suggested by terms such as "like heaven" and "promised land". Britain was reportedly sanctified in the discourse of those who had already migrated and it acquired spiritual character and significance in the minds of prospective migrants. Respondents highlighted this (spiritual) dimension of migration to Britain in their own accounts of their decision-making. Clearly, such thinking provided individuals, psychologically, with the prospect of self-enhancement, since it enabled them to visualise a transition from a negative social setting (which Jamal described) to a positively evaluated social setting with scope for self-enhancement. Identification with a positively evaluated context provided individuals

\footnotetext{
${ }^{2}$ A social representation is essentially a social construction of reality, which is elaborated by a group or society in order to facilitate communication and behaviour (Moscovici, 1988).

${ }^{3}$ This term is used to refer to the (South Asian) friends and family members who have remained in the Indian Subcontinent, with whom many BSA retain contact (in various different ways). While they share an ethnic identity (e.g. as Indians), they do not necessarily share a national identity.
} 
with scope for enhancing self-esteem and, thus, migration to Britain would allow for a positive self-conception (Gecas, 1982).

Moreover, Britain was sanctified in the minds of prospective migrants because of the opportunities it appeared to offer:

[We were told] that money grows on trees and that people become millionaires over night. We all believed it because she was way above us, her standard was way, you know, she was going places (Ram,Indian)

Ram's aunt reportedly constructed Britain as a context in which "money grows on trees" and in which "people become millionaires over night", which encouraged prospective migrants to imagine the social and economic benefits of migration. These representations focused upon the economic dimension of participants' lives which was of phenomenological concern. Indeed, participants recollected the intense poverty within the "homeland" and its negative socio-psychological consequences:

In our village people were so poor and there was no work or anything. I remember feeling so useless because I couldn't bring any money in to feed my family (Gurdeep,Indian)

We didn't have no nurses or doctors when babies were born in the village. It was my sisters who delivered the child. Can you imagine that? (Amar,Indian)

The psychological consequences of hardship and poverty were considerable. In the patriarchal homeland context, male participants reported "feeling so useless" since they were unable to fulfil the duties regarded as being associated with the familial patriarch. Amar constructed his homeland as lacking what would be considered "basic" resources required for survival, such as access to medical assistance during childbirth. Similarly, Gurdeep attributed the hunger experienced by his family members to their lack of financial resources. His use of the transitive verb "to feed" suggested that it was specifically his responsibility to maintain his family. Gurdeep's memory of "feeling so useless" as a consequence of his inability to fulfil this role highlighted the potential threat to self-efficacy. He felt unable to provide for his family in the way socially expected of him. However, social representations of Britain constructed migration as a vehicle for escaping poverty in the Subcontinent and for improving the living standards of family members. These representations reportedly provided participants with an imagined means of enhancing those identity principles which were susceptible to threat. For Gurdeep, they could provide indirect benefits for self-efficacy, since the prospect of migration provided feelings of competence and control vis-à-vis his perceived familial responsibilities.

For respondents, the pervasive representations of affluence and social mobility in Britain appeared to be supported by "visual evidence" of expensive clothing and jewellery exhibited by BSA during their visits to the Subcontinent. The visiting migrants reportedly induced excitement and hope among SAS and contributed to their decisions to embark upon their journeys to Britain:

He [a migrant] came with a small radio for me and it had the whole village at my house [..] We took it in turns to listen to it. We just couldn't believe that he could afford that (Gurdeep,Indian) 
They [expatriates] came with gold around their necks, rings on their fingers, the lot. That's what Britain was for us [...] that's why I left for Britain (Jamal,Pakistani)

The abstract concepts of affluence and social mobility were imbued with a concrete existence, since individuals invoked specific concrete objects as symbols representing these concepts (Moscovici, 1988). For instance, the "small radio" evidenced the wealth of migrant individuals in Gurdeep's mind, while for Jamal the "gold around their necks, rings on their fingers" came to symbolise Britain as a nation. This essentially reinforced the social representations of wealth and social mobility disseminated by migrant individuals, positioning them within a symbolic reality. Moreover, this allowed individuals to imagine affluence and social mobility. Thus, the prospect of migrating to Britain clearly enhanced self-efficacy. To invoke Kelman's (1997) aforementioned typology of psychological attachment to the nation, it may appear that respondents' hopes and dreams for economic advancement in Britain induced what was to become an instrumental national attachment to Britain. However, the economic motive for migration was not the only one (cf. Hiro, 1973).

\section{Deriving Pride and Honour in the Homeland}

Self-positioning within the "migrant" role provided individuals with feelings of pride and social superiority within the family circle and broader community, partly because it enabled them to fulfil their perceived "duty" to provide support to family members in the homeland:

I did support my family a lot and that was a great feeling. I was a young boy and that made me feel like the man of the house [..] I was sending more money than they earned in a whole year (Iqbal,Pakistani)

Like Iqbal, several participants reported that the ability to support family members financially enhanced self-esteem. In the extract above, this enhanced sense of self-esteem was related to Iqbal's achievement of patriarchal status within the family context. He felt that his family members now depended upon him (Burholt, 2004). Occupancy of this desirable social position facilitated the maintenance of a positive self-conception (Gecas, 1982), as indicated by Iqbal's description of how he felt. Vignoles, Chryssochoou and Breakwell (2000) have observed that the concept of position, which refers to one's position within social relationships (e.g. family units), constitutes a source of distinctiveness, since the individual is located within the interpersonal network of their family as a (positively) distinguished individual. In Iqbal's account, it was evident that the feelings of distinctiveness derived from this position within the interpersonal network were positive and beneficial psychologically. Moreover, the downward comparison between himself and SAS (the observation that he "was sending more money than they earned in a whole year") endowed him with feelings of superiority and pride, which also bolstered self-esteem (Wills, 1981). This is consistent with the earlier observation (in relation to Gurdeep's above-cited account) that the patriarch's perceived inability to support his family financially may be aversive for self-esteem.

There was also a pervasive sense of interpersonal pride, since individuals themselves reported feeling respected and valued by SAS. Most respondents identified the heightened sense of respect from relevant others in the village context as one of the most psychologically rewarding consequences of migration:

Respect is all I ask for. I don't need their money or anything, just their respect (Usha,Indian) 
If they [SAS] treat me with due respect, I'll carry on going (Iqbal,Pakistani)

Participants expected respect from SAS, for whom they felt that they had made sacrifices such as migration to Britain. While participants viewed SAS as benefiting primarily from monetary aid (see Abdul's quote below), they themselves were more concerned with the ensuing honour and respect that could be derived from interactions with SAS. This is consistent with the observation that "izzat" (respect and honour) is central to South Asian culture (Ghuman, 2003). The interviewees' accounts indicated that "izzat" bolstered their self-esteem - it endowed them with a feeling of self-worth within the village context:

You hear the things they say and it makes me feel really happy and good about myself. I feel I've helped people and they appreciate it. It's a great, special feeling (Arti,Indian)

Respect and honour constituted positive by-products of migrants' enhanced self-efficacy at the interpersonal level - others came to honour and respect them because of the assistance that the migrants had offered. Respondents believed that migration enabled them to acquire "high social status" and that this status was clearly manifested in the respect that they received from SAS. As Arti indicated, this was beneficial for self-esteem. While some individuals reported feeling under-valued in Britain, especially by the White British majority and sometimes by second-generation BSA (Jaspal, 2011), the respect and honour derived from SAS compensated for such potential threats to self-esteem. This appeared to constitute an important reason for continued contact with the homeland. They themselves derived the high social status which they had once attributed to BSA visitors to their villages.

Participants felt that they were less distinctive from, or less positively evaluated by, other ingroup members (and especially their parents) prior to migration. This elucidated the threatening position occupied by individuals prior to migration:

I was nothing when I left, you know? My mum and dad told me that they regretted having me because I was going to amount to nothing, but when I came back with the pounds (laughs) [..] That made me love being British (Abdul,Pakistani)

I was a trouble-maker back in Pakistan (laughs). My parents couldn't wait to get rid of me [..] Britain turned me into a gentleman though (Mohammed,Pakistani)

Respondents believed that migration to Britain had provided them with opportunities for upward social mobility, and this was often juxtaposed with their poor economic conditions and low social status in the homeland. Like Abdul several individuals described their perceived social inferiority prior to migration. For instance, Mohammed invoked his former image as "a trouble-maker." The perception of poor social status is unlikely to be conducive to a positive self-conception. Moreover, Abdul's account suggested possible threats to distinctiveness given that he was allegedly "nothing" prior to migration - he did not stand out from others and was not recognised for any particular trait. Similarly, other participants indicated that they lacked distinctiveness in the homeland context:

I was just a village kid - one of them. Nothing special about me. I wasn't good at anything. I wasn't even good in the fields [...] Nobody would remember my name if I didn't leave actually. Now it's different. They know me and welcome me when I come (Satvinder,Indian) 
Satvinder regarded himself as an interchangeable, rather than distinctive, member of his community. He believed that he had no remarkable skills which might enhance his distinctiveness, not even within the agricultural domain. These observations suggested that participants occupied a threatening position (for identity) prior to migration - they perceived little distinctiveness and self-esteem - but that migration offered the means for enhancing these very principles of identity. For Satvinder too, migration altered his social position by bolstering his distinctiveness as an economic contributor to his family and to the village community (Burholt, 2004).

Similarly, as Abdul indicated, there was reportedly a significant change in SAS' perceptions of migrants upon their return to the homeland "with the pounds." Many participants derived a great sense of pride from this enhanced social position, because it marked a significant improvement in their social standing. Given that an improvement in social status may be beneficial for self-esteem, the phenomenon perceived to underlie this improvement in social status is likely to be embraced by the individual and viewed as more central to identity (Vignoles, 2011). Accordingly, for Abdul, this appeared to engender a more sentimental attachment to Britain. Karim too manifested a sentimental, rather than instrumental, attachment to Britain:

When I think of this place, I do feel an emotional kind of link with it. It's my home. It's made me who I am in a way [..] I'd be sad if I left. I wouldn't want to leave. It's my home, Britain is, and I love it (Karim,Pakistani)

For most interviewees, their initial psychological connection with Britain was indeed an instrumental one, since upward social mobility through financial gain was the primary aim (Hiro, 1973). However, having acquired a privileged status within the homeland context, some individuals developed a more sentimental attachment - Karim highlighted his "emotional link" to Britain and referred to it as his "home". Although participants widely employed the term "homeland" when referring to their country of origin, Britain too appeared to have acquired the position of "home". This is not necessarily because of the construction of a cohesive ethnic ingroup community in Britain but rather because of the psychological benefits (e.g. self-esteem,self-efficacy) provided by life in Britain (cf. Ballard, 1994).

Like Karim, several respondents indicated that Britain had contributed to their position and identity: "It's made me who I am." This can be understood within the context of threatened identity - individuals reported lacking social and economic status in their ethnic homeland, which they acquired as a direct result of migration. Abdul's feelings of pride and happiness in self-identification as British were evident in his account of migration to Britain:

Being British is something very beautiful and I'm really proud of it [... [I feel] proud and very happy. It is a good feeling to be British (Abdul,Pakistani)

Abdul described his British national identity as "beautiful" because he believed that he had derived psychological benefits from it. Pride tends not be associated with instrumental national attachment, which highlighted the sentimental nature of Abdul's attachment to Britain. This indicated that the boundaries between instrumental and sentimental forms of national attachment may be less clear-cut than originally assumed and that a transition from national to sentimental attachment may ensue from perceived benefits for identity processes (cf. Kelman, 1997). 
However, the embracement of Britishness did not result in diminished attachment to the ethnic homeland. The aforementioned need for respect and honour was reflected in many individuals' utopian vision of return to the homeland, which some authors have called the "myth of return" (Anwar, 1979). Some, in fact, contemplated returning to the Subcontinent:

Yeah, I'd like to go back [to India] and settle there. I'd be treated with a lot more respect than over here, I'll tell you that [...] [because] people know you've done something for them there because here no one cares (Gurdeep,Indian)

The need for self-esteem and positive distinctiveness, which are derived from "izzat," led participants like Gurdeep to fantasise about resettlement in the homeland. This can be described as fantasy because most interviewees doubted that they would ever really re-settle in the Subcontinent - for some, this was merely "whimsical speculation" that could bolster identity (Breakwell, 1986,88). The hope for settlement was grounded principally in participants' quest for "izzat," which was perceived as being more readily available in the homeland context than in Britain. Gurdeep, in particular, expressed his desire to be acknowledged for his benevolence and made a comparison between the homeland context, in which he constructed himself as a distinctive member of the ingroup, and the British context ("here"), in which his distinctiveness and self-esteem were apparently under threat. This notion can be better understood in the context of first-generation BSAs' perception that they are not adequately respected and valued in Britain (see Jaspal, 2011). Conversely, continued close contact with the homeland could ensure the maintenance and enhancement of selfesteem and distinctiveness. It is noteworthy that, among several participants, self-positioning within the homeland context prior to migration was perceived as threatening the same principles. Yet, in later life, it appeared that a utopian vision of the homeland had developed, which had positive outcomes for identity processes.

\section{The Psychological Trauma of Migration}

Participants' accounts elucidated some of the psychological downsides of migration to Britain, including feelings of nostalgia and a sense of "Otherness."

\section{Loss and Nostalgia: Remembering the Homeland}

Although all participants had been resident in Britain for decades, several expressed a continuous, poignant sense of loss as a consequence of migration. This engendered feelings of nostalgia towards the homeland:

There are things that I miss now and I didn't realise I would miss them when I left. Just small things like the smell of the village and the sounds that you hear in the village that you don't have over here [..] I miss the sense of community that you just don't have over here because everyone is busy living their lives and they don't have any time for anyone else (Usha,Indian)

God, I wish I could wake up and smell the village air every morning [..] This place smells different (Hassan,Pakistani)

Interviewees nostalgically invoked their olfactory and auditory sensory experiences in the homeland. The sensory exploration of place (such as seeing, smelling and hearing) has been 
identified as a major mode of psychologically "appropriating" space or incorporating it into the self-concept. This may underlie the sense of loss experienced by some participants subsequent to migration. For Hassan, the smell of "the village air" could not be reproduced in his "home away from home," to use Ballard's (1994) term. Thus, although anthropologists have argued that ethnic minority communities have been "re-constructed" within the diaspora (see Ballard, 1994), participants clearly lamented the loss of these sensory experiences but also "the sense of community" in Britain in contrast to the homeland.

"Loss," by definition, suggests a sense of discontinuity between past, present and possibly future and, thus, it has the ability to pose threats to continuity. Indeed, Usha's account attested to the unexpectedness of the change: "there are things I miss now and I didn't realise I would." Individuals will cope with threats to continuity as a result of change by constructing continuous life narratives with progressions and turning points connecting past, present and future (McAdams, 2001). In Usha's account, the change was perceived as unexpected and poignant. Like Usha, some participants believed that the sense of community in the homeland was impossible to reconstruct in Britain:

\section{Interviewer: What about Asians here? Don't you feel like a community?}

Iqbal (Pakistani): No, no. They [Asians here] haven't got a minute to spare. We haven't because we're working and we've got our priorities. This isn't Pakistan and it's not going to be Pakistan even if all of Pakistan comes here.

Individuals' sense of continuity might be threatened as a result of their actual inability to reproduce their "communities" in their host countries. Furthermore, the belonging principle may be imperilled by the absence of perceived closeness to others, which was exemplified by respondents' perception that ingroup members have little sense of commitment towards other group members, primarily due to the busy lifestyle in Britain (Ballard, 1994). Like Iqbal and Usha, many interviewees provided examples of disappointing experiences with members of their ethnic ingroup, which attested to the perceived loss of community. For instance, one participant recounted his community's response to the death of his father and indicated that, unlike in the homeland, members of his ethnic community had not partaken in the cultural tradition of collective mourning (referred to as "afsos" in Punjabi) (Wakil, 1970). Experiences of this kind rendered salient the cultural differences between BSA and SAS and, thus, the sense of loss.

Participants indicated that contact with the homeland could render salient differences between past and present, which in turn aggravated the sense of loss:

It's not the same over there. When you go back to India after all this time, you don't find the same things and that does bother you a bit. It hurts actually. You feel quite rejected because you're living with gore [White people] [..] but back home in India it's all changing (Gurdeep,Indian)

Gurdeep's perception of change in his village seemed to jeopardise continuity, particularly because the change was perceived to have arisen during his absence from the homeland. Absence from a changing social context, to which one personally lays claim, may threaten continuity, because one perceives no personal participation and agency in the change. This may problematise the task of constructing a continuous life narrative with progressions and 
turning points (McAdams, 2001). Interviewees expected the homeland to remain static and, thus, many were disappointed to find that changes had indeed taken place in their absence:

I don't recognise our village. It's just like a city now. All these shops and people from other villages and cities and even states. It's horrible. It's like my childhood is really gone now when I go back. I can't see my childhood (Gurinder,Indian)

I thought it'd be the same place when I went back [...] I couldn't recognise the place (Iqbal,Pakistani)

Gurinder was troubled by the changes that he perceived in his village because these changes disrupted the unifying psychological thread between past and present. Given that the village symbolised his childhood, the changes that had taken place in the village (e.g. the construction of shops) were perceived as a rupture with the village he had known as a child. Indeed, for him, the village had been transformed into a "city." Like Gurinder, most individuals perceived no involvement or agency in the changes that had taken place, which was threatening for identity. Indeed, for most interviewees, holidays to the homeland were generally regarded as a means of "re-connecting" with their past and, thus, there was an expectation for the continuity principle to be maintained and enhanced in the homeland. Gurdeep expected temporal continuity in the homeland and, thus, the lack of continuity was threatening. Belonging was also threatened - Gurdeep reported feeling "rejected" as a result of change in his absence.

Although respondents indicated that first-hand contact with the homeland (through family holidays to the Subcontinent, for instance) constituted a means of re-connecting with the past, there was evidence that this could accentuate the threat to identity associated with migration to Britain.

\section{Migration and "Otherness"}

It has been reported in previous research that first-generation BSA may experience threats to belonging in Britain due to experiences of racism and discrimination (Jaspal, 2011). Participants' accounts highlighted an additional dimension of their perceived rejection, namely exclusion from the homeland context from ethnic ingroup members. Although SAS reportedly valued and esteemed BSA, they nonetheless perceived BSA as an outgroup:

They [SAS] don't actually want to see people going from there and if you do they don't want much to do with you because they just think 'Oh he's going to go back anyway. He's not staying here with us, is he?' [...] So the gap is there even with Indians (Gurdeep,Indian)

Gurdeep was one of several individuals to identify intergroup tensions with SAS, which were attributed to a perceived "gap" between SAS and BSA. BSA were allegedly viewed by SAS as temporary visitors to the homeland, which resulted in their exclusion from the ingroup. They were no longer regarded as "authentic" members of the ingroup (see Vannini and Franzese, 2008 for a discussion of authenticity in relation to identity), and were reportedly excluded from discussions about issues relevant to the village. Given respondents' continued identification with the homeland, this was threatening for identity. Some participants perceived their departure from the homeland as a sacrifice for SAS. Their reported intention was to improve living conditions in the homeland by providing financial support, but their 
own early experiences were characterised by social and economic struggles (Jaspal, 2011; Ballard, 1994). Consequently, the prospect of exclusion (e.g. through social change; the identification of a "gap") could threaten belonging, particularly since there understandably exists the expectation that one should be included within the group and accepted by other group members (Jaspal, 2011). Moreover, some participants came to regard themselves as "special" members of the ingroup. Consequently, the perception of a "gap" may violate this self-image, resulting in threats to continuity of self-definition.

Britishness:

Several interviewees believed that SAS viewed them as "outsiders" because of their

My children were born here and they're English-speaking so obviously when we go back to India we speak some English together too and that's something that makes them think we're a little different [... Mostly I blend in well but it's when I'm with my husband and children that they see that I'm quite British too myself (Usha,Indian)

If you've left, that's it, you speak the language and you just get treated like an outsider, like you're that country's person now, not Indian. I think it's backwardness about us not being Indian and British at the same time, like being unable to be it (Ram,Indian)

BSA have multiple identities, which are activated in accordance with context (Cohen, 2000). Both Usha and Ram regarded the English language, a symbol of Britishness (Julios, 2008), as impeding "re-integration" in the homeland, since this could render salient intergroup differences between BSA and SAS. Indeed, Jaspal and Coyle (2010) have argued that use of the non-normative languages in particular social contexts may render salient intergroup differences. Usha attributed the perception of difference among SAS to the presence of her British-born children, who laid claim to the English language, a symbol of Britishness. Thus, in their absence, she perceived feelings of acceptance and inclusion within the Indian ingroup, since they were perceived as British. It is likely that belonging will be threatened when one's self-categorisation as a group member is not "validated" by other members of the social group to which one lays claim (see Jaspal and Cinnirella, 2012).

Usha's account echoed Ram's more explicit observation that emigration from India, settlement in a foreign country and the use of self-aspects associated with one's host country were conducive to "otherisation" in the homeland. This essentially constructed Britishness and Indian-ness as incompatible and, thus, threatening for coherence. While these identities may initially be perceived to be compatible, the perception of others' problematisation of these inter-connected identities may problematise the coherence principle. Meanwhile, the belonging principle may be susceptible to threat due to the perceived lack of acceptance and inclusion due to individuals' use of "outgroup self-aspects" (e.g. the English language) and to their positioning as "outsiders."

\section{DISCUSSION}

This study demonstrates that migration can have an important impact for identity processes, one's relations with both Britishness and one's ethnic homeland, and the qualitative nature of one's attachment to these contexts. It illustrates the profound socio-psychological implications of migration and how, decades after migration, it can continue to shape one's identity and attachment to relevant social categories. 
For most participants, life in the Subcontinent had been difficult - both economically and psychologically - and accordingly they perceived threats to their distinctiveness, selfesteem and self-efficacy. There was a perception that, living in the homeland, they would be unable to fulfil the roles and responsibilities associated with their social position, that they would fail to derive distinctiveness from others and that they would be unable to derive a positive self-conception (Breakwell, 1986). Migration, conversely, offered a means of coping with a chronically threatened identity. It allowed individuals to imagine a more positively evaluated identity position, underpinned by feelings of self-esteem, distinctiveness and selfefficacy, the very principles of identity that were susceptible to threat in the homeland. It allowed them to make a psychological transition from being SAS (a threatening social category) to being BSA (a positively evaluated category). In short, migration provided individuals with the psychological prospect of self-enhancement. Following migration to Britain, interviewees reported a more positive self-conception, enhanced self-efficacy and greater (positive) distinctiveness, principally because, as BSA, they acquired respect, honour and admiration from members of their ethnic group (in the homeland). Migration to Britain facilitated social, economic and psychological mobility. Although migration bolstered the formerly threatened principles of identity, this did not suddenly become the only source of identity enhancement. The ethnic homeland retained a position of symbolic importance for individuals, enabling them to derive respect and honour and to engage in downward comparison with SAS (Wills, 1981).

Migration to Britain was not psychologically unproblematic - consistent with previous research (Timotijevic and Breakwell, 2000), it can be conceptualised as entailing traumatic elements. Interviewees highlighted their feelings of nostalgia about the ethnic homeland - they began to lament the loss of important ethno-cultural and ethno-religious tenets, basic sensory experiences in the homeland and, perhaps most importantly, the sense of "community" which they believed they lacked in Britain. This is an interesting observation in view of anthropological research that implies that BSA have re-constructed a "community away from home" (e.g. Ballard, 1994). What the present research shows is that this sense of community is, in many cases, incomplete and psychologically threatening. This could be attributed to the vastly different cultural orientations of Britain and the Subcontinent respectively - while collectivism is valued within South Asian communities, many migrants found themselves having to develop a more individualistic cultural orientation in order to achieve their aims originally associated with migration. Moreover, there is some evidence that the changing identities, aspirations and cultural patterns of the second-generation in turn had an impact on first-generation BSAs' contact with their communities. For instance, the perception that second-generation BSAs' behaviour was inconsistent with the norms and values of South Asian culture encouraged some first-generation BSA to avoid their respective communities in order to "save face" (Ghuman, 2003; Jaspal, 2011). However, consistent with IPT, BSA do attempt to cope with these threats. They continue to visit the homeland, maintain social and economic arrangements with SAS and reproduce ethnic, cultural and religious traditions in their communities away from home (Burholt, 2004).

Most respondents highlighted their belief that their relationship with the homeland had undergone undesirable changes. For instance, they believed that the homeland had radically changed in their absence and that they had had no agency in these changes, something which was threatening for their sense of continuity. Moreover, several of them felt that they were excluded by SAS and regarded as outsiders in a context that they viewed as "home." In some cases, they were viewed as "inauthentic" members of the ethnic ingroup, because of their Britishness. Individuals believed that they derived "excessive" distinctiveness from people with whom they wished to share a social identity. This could be problematic given that individuals had come to view the ethnic homeland as an important 
source of belonging in view of discrimination faced in Britain (Hussain and Bagguley, 2005). Yet, BSA may face a bi-dimensional exclusion from both the Britishness and ethnic ingroup members within the homeland.

This study demonstrates the inherent complexity of migration when viewed from the perspective of identity processes. Migration can be represented psychologically as both a positive and negative phenomenon. When BSA think about migration positively (that is, as a source of economic, social and psychological mobility), they may accentuate their attachment to Britain. While this may have originally constituted an instrumental attachment, close attention to participants' accounts elucidated the unambiguously sentimental character of their Britishness (Kelman, 1997). When respondents lamented migration, they appeared to resurrect the "myth of return" (Anwar, 1979). This was particularly prevalent when individuals reflected on their inability to "integrate" within British society, which many attributed to their poor English language skills, settlement in largely South Asian enclaves in British towns and cities and more general discrimination from the White British majority. The data demonstrate the inter-relations between perceptions of migration and British national identity. It may well be that the key to understanding the nature and extent of British national identity among first-generation ethnic minorities lies in the study of migration itself.

Much previous socio-psychological research has understandably focused upon acculturation in the host society given the social and political desirability of facilitating "integration" among ethnic minorities (Sam and Berry, 2006). However, an additional, yet equally important, dimension of migration is migrants' sense of attachment to their ethnic homeland, which, in many cases, remains phenomenologically important. The data suggest that BSA strategically manoeuvre between identity elements (e.g. laying claim to Britishness in some contexts and desiring resettlement in the Subcontinent in others) in order to enhance identity processes. Indeed, this reflects the central assumption of IPT that individuals possess self-agency in constructing and monitoring identity and that they are resourceful in optimising identity processes. Yet, despite the resilience and resourcefulness of migrants, migration can be threatening for identity, often forcing individuals to re-think their identities, positions and relationships.

People do cope with identity threat but they do this to varying degrees and with varying levels of success. In the case of first-generation BSA, it appears that they juggle their citizenship, national and ethnic identities in order to optimise their social and psychological wellbeing. Unlike second-generation BSA who tend to regard the ethnic homeland primarily as a holiday destination (Harris, 2006; Jaspal, 2011), the first-generation may feel a greater attachment to the homeland given their socio-psychological investments in this context and, therefore, depend upon continued contact with the homeland for identity enhancement. Britishness too clearly occupies an important position in the self-concept, as this is often perceived as having provided them with the socio-economic opportunities they and their children now possess. This study highlights the complexity of identity processes among the first-generation and migrants, more generally, as well as the intricate ways in which they attempt to cope with the threats associated with life in the homeland and migration to Britain. While this qualitative study focused upon the shared experiences of both British Pakistanis and British Indians in the context of migration and its impact for identity, future research should investigate potential differences in these groups' early experiences and in their current levels of identification with Britishness and the ethnic homeland. Quantitative methods would allow for systematic analyses of difference. Furthermore, there has been only limited research into other South Asian migrant groups, such as Bangladeshis and Sri Lankans. Research with these groups would benefit the field of South Asian diaspora studies. It is hoped that this article will encourage researchers and policy-makers to acknowledge the 
importance of researching BSA who continue to construct, negotiate and juggle their identities as British, South Asian and migrants.

\section{REFERENCES}

Anwar, Mohammed. 1979. The Myth of Return, Pakistanis in Britain. London: Heinemann Ballard, Roger, ed. 1994. Desh Pardesh: the South Asian experience in Britain. London: C. Hurst \& Co.

Brah, Avtar. 1996. Cartographies of Diaspora: Contesting Identities. London: Routledge

Braun, Virginia and Victoria Clarke. 2006. "Using thematic analysis in psychology." Qualitative Research in Psychology, 3: 77-101.

Breakwell, Glynis M. 1986. Coping with threatened identities. London: Methuen.

Burholt, Vanessa. 2004. "Transnationalism, economic transfers and families' ties: intercontinental contacts of older Gujaratis, Punjabis and Sylhetis in Birmingham with families abroad." Ethnic and Racial Studies 27 (5): 800-829.

Chatterji, Joya and David Washbrook, eds. 2013. Routledge Handbook of the South Asian Diaspora. London: Routledge.

Cohen, Robin. 2000. "The incredible vagueness of being British/English." International Affairs 76 (3): 575-82

Gecas, Viktor. 1982. “The self-concept.” Annual Review of Sociology 8: 1-33.

Ghuman, Paul A.S. 2000. "Acculturation of South Asian adolescents in Australia." British Journal of Educational Psychology 70: 305-316.

Ghuman, Paul A.S. 2003. Double loyalties: South Asian adolescents in the West. Cardiff: University of Wales Press.

Harris, Roxy. 2006. New ethnicities and language use. Basingstoke: Palgrave Macmillan.

Hegde, Radha S. 1998. "Swinging the Trapeze: The Negotiation of Identity Among Asian Indian Immigrant Women in the United States." In Communication and Identity across Cultures, edited by Dolores Tanno and Alberto Gonzalez, 34-55. Thousand Oaks, CA: Sage.

Hiro, Dino. 1973. Black British, White British. Harmondsworth: Penguin.

Hussain, Yasmin and Paul Bagguley. 2005. "Citizenship, Ethnicity and Identity: British Pakistanis after the 2001 'riots'." Sociology 39 (3): 407-25.

Jacobson, Jessica. 1997. “Perceptions of Britishness.” Nations and Nationalism 3 (2): 181-99.

Jaspal, Rusi. 2011. "The construction and management of national and ethnic identities among British South Asians: an identity process theory approach.” Ph.D. diss, University of London. 
Jaspal, Rusi, and Glynis M. Breakwell, eds. 2014. Identity Process Theory: Identity, Social Action and Social Change. Cambridge: Cambridge University Press.

Jaspal, Rusi, and Marco Cinnirella. 2012. "The construction of ethnic identity: insights from identity process theory." Ethnicities 12 (5): 503-530.

Jaspal, Rusi and Adrian Coyle. 2010. “"My language, my people': language and ethnic identity among British-born South Asians." South Asian Diaspora 2 (2): 201-218.

Julios, Christina. 2008. Contemporary British identity: British language, migrants and public discourse. Aldershot: Ashgate.

Kelman, Herbert C. 1997. "Nationalism, patriotism, and national identity: Socialpsychological dimensions." In Patriotism in the lives of individuals and nations, edited by Daniel Bar-Tal and Ervin Staub, 165-189. Chicago: Nelson-Hall.

McAdams, Dan P. 2001. "The psychology of life stories." Review of General Psychology 5: $100-122$.

Moscovici, Serge. 1988. "Notes towards a description of social representations." European Journal of Social Psychology 18: 211-50.

Pargament, Kenneth I. and Annette Mahoney. 2005. "Sacred matters: sanctification as a vital topic for the psychology of religion." International Journal for the Psychology of Religion 15: 179-198.

Robinson, Lena. 2009. "Cultural identity and acculturation preferences among South Asian adolescents in Britain: an exploratory study.” Children and Society 23 (6): 442-454.

Saeed, Amir. 2007. "Media, racism and Islamophobia: the representation of Islam and Muslims in the media." Sociology Compass 1 (2): 443-462.

Safran, William. 1991. "Diasporas in modern societies: myths of homeland and return." Diaspora 1 (1): 83-99.

Sam, David and John Berry, eds. 2006. Cambridge handbook of acculturation psychology. Cambridge: Cambridge University Press.

Timotijevic, Lada and Glynis M. Breakwell. (2000). "Migration and threat to identity." Journal of Community and Applied Social Psychology 10: 355-372.

Vadher, Kiren and Martyn Barrett. 2009. "Boundaries of Britishness in British Indian and Pakistani young adults.” Journal of Community and Applied Social Psychology 19: 442-458.

Vannini, Phillip and Alexis Franzese. 2008. "Authenticity of Self: Conceptualization, Personal Experience, and Practice.” Sociology Compass 2/5: 1621-37.

Vertovec, Steven. 2009. Transnationalism. London: Taylor \& Francis. 
Vignoles, Vivian L., Xenia Chryssochoou, and Glynis M. Breakwell. 2000. "The distinctiveness principle: identity, meaning and the bounds of cultural relativity." Personality and Social Psychology Review 4: 337-354.

Wakil, Parvez A. 1970. "Explorations into the Kin-Networks of the Punjabi Society: A Preliminary Statement.” Journal of Marriage and Family 32 (4): 700-707.

Wills, Thomas A. 1981. "Downward comparison principles in social psychology." Psychological Bulletin 90 (2): 245-271. 